\title{
Functional FGFR4 Gly388Arg polymorphism contributes to cancer susceptibility: Evidence from meta-analysis
}

\author{
Si-Wei Xiong ${ }^{1, *}$, Jianqun $\mathrm{Ma}^{2, *}$, Fen Feng ${ }^{3, *}$, Wen Fu ${ }^{4}$, Shan-Rong Shu ${ }^{5}$, Tianjiao

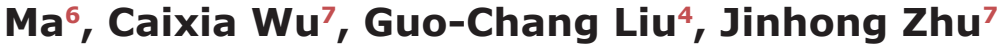 \\ ${ }^{1}$ Department of Urology, Guangzhou First People's Hospital, Guangzhou Medical University, Guangzhou 510180, Guangdong, \\ China \\ ${ }^{2}$ Department of Thoracic Surgery, Harbin Medical University Cancer Hospital, Harbin 150040, Heilongjiang, China \\ ${ }^{3}$ Department of Gastroenterology, The First People's Hospital of Foshan (Affiliated Foshan Hospital of Sun Yat-sen University), \\ Foshan 528000, Guangdong, China \\ ${ }^{4}$ Department of Pediatric Urology, Department of Pediatric Surgery, Guangzhou Institute of Pediatrics, Guangzhou Women \\ and Children's Medical Center, Guangzhou Medical University, Guangzhou 510623, Guangdong, China \\ ${ }^{5}$ Department of Gynecology and Obstetrics, The First Affiliated Hospital of Jinan University, Guangzhou 510630, Guangdong, \\ China \\ ${ }^{6}$ Department of Internal Medicine, Harbin Medical University, Harbin 150081, Heilongjiang, China \\ ${ }^{7}$ Molecular Epidemiology Laboratory and Department of Laboratory Medicine, Harbin Medical University Cancer Hospital, \\ Harbin 150040, Heilongjiang, China \\ *These authors have contributed equally to this work \\ Correspondence to: Si-Wei Xiong, email: sw_xiong@hotmail.com \\ Jinhong Zhu, email: jinhongzhu625@gmail.com
}

Keywords: FGFR4, Gly388Arg, polymorphism, cancer, meta-analysis

Received: November 09, $2016 \quad$ Accepted: February 07, 2017

Published: February 28, 2017

Copyright: Xiong et al. This is an open-access article distributed under the terms of the Creative Commons Attribution License (CC-BY), which permits unrestricted use, distribution, and reproduction in any medium, provided the original author and source are credited

\section{ABSTRACT}

Fibroblast growth factor receptor 4 (FGFR4) is a member of receptor tyrosine kinase family. A functional Gly388Arg (rs351855 G>A) polymorphism in FGFR4 gene causes a glycine-to-arginine change at codon 388 within the transmembrane domain of the receptor. Although the FGFR4 rs351855 G>A polymorphism has been implicated in cancer development, its association with cancer risk remains controversial. Here, we have systematically analyzed the association between the rs351855 G>A polymorphism and cancer risk by performing a meta-analysis of 27 studies consisting of 8,682 cases and 9,731 controls. Odds ratios (ORs) and $95 \%$ confidence intervals (CIs) were calculated to measure the strength of the association. The rs351855 G>A polymorphism was associated with an increased cancer risk under the recessive model $(O R=1.19,95 \% \mathrm{CI}=1.01-1.41)$. Stratified analysis by cancer type indicated the rs351855 G>A polymorphism was associated with an increased risk of breast and prostate cancer, but a decreased risk of lung cancer. This meta-analysis demonstrates the FGFR rs351855 G>A polymorphism is associated with increased cancer risk and suggests it could potentially serve as a chemotherapeutic target or biomarker to screen high-risk individuals.

\section{INTRODUCTION}

Cancer represents an enormous economic burden on society in both developing and developed countries. Based on the GLOBOCAN 2012 estimates, there were about 14.1 million new cancer cases in 2012, and 8.2 million deaths [1]. Cancer is a complex multifaceted disease that results from gene-environment interactions. Apart from the lifestyles associated with an increased risk of a number of common cancers, genetic variations, including single nucleotide polymorphism (SNP), have been known to affect cancer susceptibility. 
Fibroblast growth factor receptors (FGFRs), composed of four related proteins (FGFR1-4), belong to the receptor tyrosine kinase (RTK) family. To date, more than 18 FGF ligands have been identified [2]. The binding of ligands to FGFRs triggers several downstream signal transduction cascades that are activated in cancer, including phospholipase C (PLC), phosphatidylinositol 3-kinase (PI3K), signal transducer and activator of transcription (STAT), as well as mitogen-activated protein kinases (MAPKs) [3, 4]. FGFRs participate in the regulation of multiple crucial biological activities, including cell proliferation and differentiation, migration, angiogenesis, and survival $[3,5,6]$. Numerous studies have indicated an aberrant FGFR signaling in carcinogenesis [2, 7, 8]. Recently, a large scale analysis of 4,853 solid tumors has revealed that $7.1 \%$ of cancers harbor FGFR aberrations, including gene amplifications (66\%), mutations (26\%), and rearrangements (8\%) [9]. Over the past decade, different types of FGFR inhibitors have been developed to treat cancer, including multi-target tyrosine kinase inhibitors, FGFR specific tyrosine kinase inhibitors (TKIs), monoclonal antibodies, and FGF ligand traps $[2,10]$.

FGFR4 is a highly versatile protein that has more than 20 known ligands [5], and is highly expressed in various types of cancer [11-16]. Overexpression of FGFR4, but not other FGFRs, stimulates membrane ruffling, resulting in increased motility of COS-7 cells [17]. The FGFR4 gene is highly polymorphic. A common nonsynonymous SNP rs351855, which causes a substitution of arginine instead of glycine in the transmembrane domain of the EGFR4 receptor (Gly388Arg) has been implicated in cancer development [18]. FGFR4 gene rs351855 $\mathrm{G}>$ A polymorphism has been associated with genetic predisposition to several types of cancer, including breast cancer [18-22], prostate cancer [23-26], head and neck cancer [27], lung cancer [28, 29], and hepatocellular carcinoma $[13,30,31]$. Unfortunately, the association between the FGFR4 gene $\mathrm{rs} 351855 \mathrm{G}>\mathrm{A}$ polymorphism and cancer risk remains controversial. To systematically analyze the association between the FGFR4 gene rs351855 G>A polymorphism and cancer risk, we have performed this meta-analysis using 27 studies consisting of 8,682 cases and 9,731 controls.

\section{RESULTS}

\section{Literature search}

We have initially analyzed 115 potentially relevant publications. After full review, 91 articles were excluded for the following reasons: 1) they were review articles or meta-analyses, 2) they did not investigate association between the FGFR4 rs351855 G>A polymorphism and cancer risk, 3) they were not case-control studies, or 4) had no enough data reported to calculate the odds ratios (ORs) and 95\% confidence intervals (CIs). One article was further excluded because of the departure from Hardy-Weinberg equilibrium (HWE) [32]. Only 23 articles consisting of 27 individual studies investigated the association between the FGFR4 rs351855 G>A polymorphism and cancer risk, and fit the eligibility criteria (Figure 1).

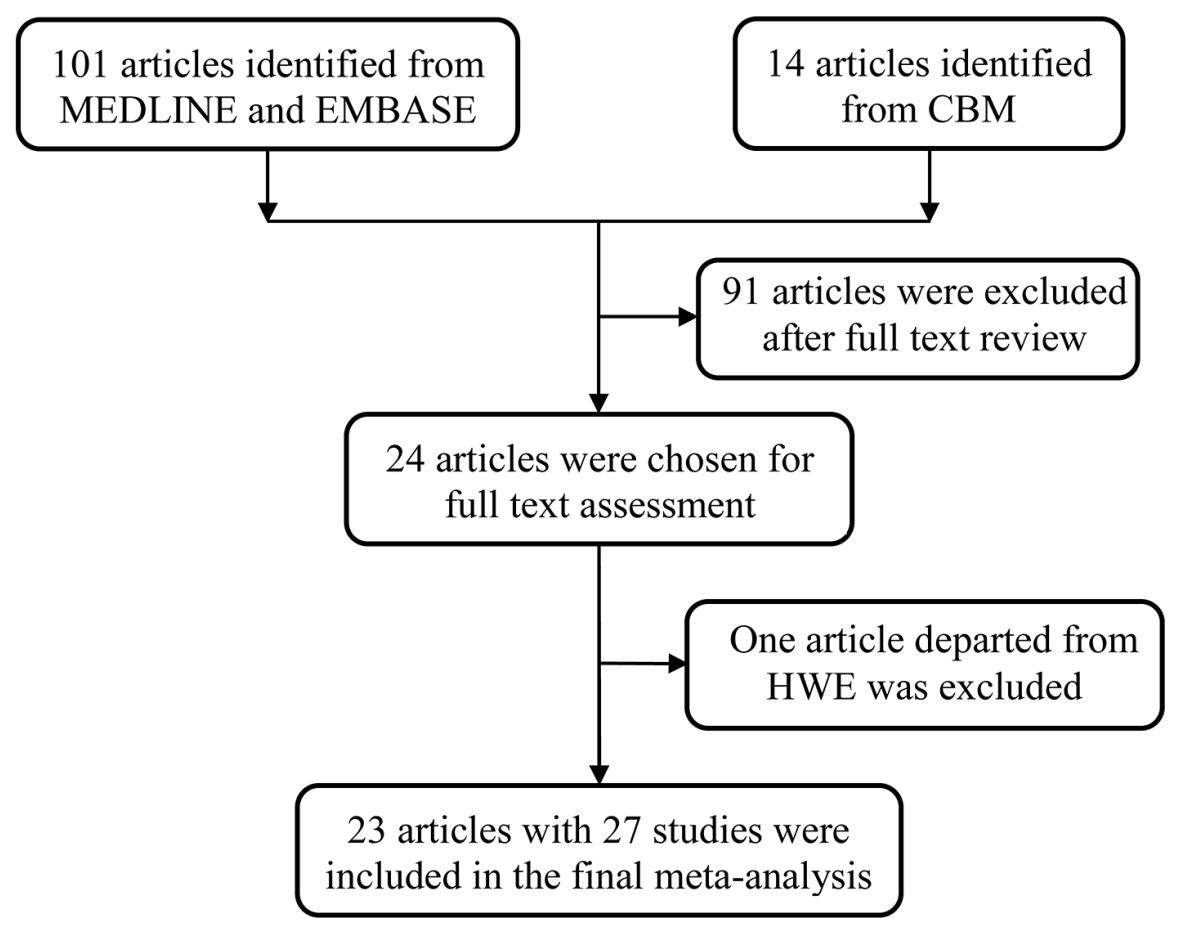

Figure 1: Flowchart of included studies. 
In total, data were obtained on 18,413 subjects (8,682 cases and 9,731 controls) from 27 studies (Table 1). The FGFR4 rs351855 G>A polymorphism was most often studied in breast cancer (6 studies) [18-22] and prostate cancer (6 studies) [23-26]. Other commonly investigated tumor types were colorectal cancer (CRC, 3 studies) [18, 20, 33], hepatocellular carcinoma (HCC, 3 studies) [13, 30, 31], and lung cancer (2 studies) [28, 29]. Additionally, studies on head and neck squamous cell carcinoma (HNSCC) [27], oral squamous cell carcinoma (OSCC) [34], non-Hodgkin lymphoma (NHL) [35], gastric cancer [36], skin cancer [37], glioblastoma [38], and sarcoma [39] were combined and categorized as "others" cancer type, since only one study for each tumor type was reported. Fourteen studies utilized population-based (PB) controls and ten had hospital-based (HB) controls. Source of control was not determined (ND) in three studies. Studies were most frequently conducted among Caucasians (14 studies), followed by Asians (11 studies), and Africans (2 studies). Eleven studies were considered as low quality (quality score $\leq 9$ ), and 16 studies $(56 \%)$ were considered as high quality studies (quality score $>9$ ).

\section{Association between FGFR4 rs351855 G>A polymorphism and cancer risk}

The main findings of the meta-analysis are shown in Table 2 and Figure 2. Overall, the FGFR4 rs351855 $\mathrm{G}>\mathrm{A}$ polymorphism was associated with increased cancer risk under the recessive model $(\mathrm{OR}=1.19,95 \% \mathrm{CI}=1.01$ 1.41). The association appeared to be negative under the homozygous $(\mathrm{OR}=1.19,95 \% \mathrm{CI}=0.98-1.44)$, heterozygous $(\mathrm{OR}=1.00,95 \% \mathrm{CI}=0.91-1.10)$, dominant (1.02, 95\% $\mathrm{CI}=0.91-1.13)$, and allele contrast models $(\mathrm{OR}=1.07,95 \%$ $\mathrm{CI}=0.98-1.16$ ). Our data suggest that individuals with AA genotype of the FGFR $4 \mathrm{rs} 351855 \mathrm{G}>\mathrm{A}$ polymorphism are at significantly increased cancer risk compared with $A G$ and GG genotypes.

Analysis stratified by cancer type indicated that FGFR4 rs351855 [A] carriers have modestly increased risk of developing breast cancer (homozygous: $\mathrm{OR}=1.73,95 \%$ $\mathrm{CI}=1.35-2.20$; recessive: $\mathrm{OR}=1.46 ; 95 \% \mathrm{CI}=1.17-1.83$; dominant: $\mathrm{OR}=1.25,95 \% \mathrm{CI}=1.02-1.52$; allele contrast: $\mathrm{OR}=1.26 ; 95 \% \mathrm{CI}=1.14-1.41)$, and prostate cancer (heterozygous: $\mathrm{OR}=1.16,95 \% \mathrm{CI}=1.02-1.32$; dominant: $\mathrm{OR}=1.20,95 \% \mathrm{CI}=1.06-1.35$; allele contrast: $\mathrm{OR}=1.22$, 95\% CI=1.06-1.41). Conversely, a modest reduction in cancer risk was found for lung cancer (homozygous: $\mathrm{OR}=0.58,95 \% \mathrm{CI}=0.40-0.83$; heterozygous: $\mathrm{OR}=0.75$, $95 \% \mathrm{CI}=0.61-0.91$, recessive: $\mathrm{OR}=0.67,95 \% \mathrm{CI}=0.53-$ 0.85 ; dominant: $\mathrm{OR}=0.70,95 \% \mathrm{CI}=0.58-0.85$; allele contrast: $\mathrm{OR}=0.76,95 \% \mathrm{CI}=0.67-0.86)$. When stratified analysis was performed by ethnicity, no association between ethnicity and cancer risk was observed among Caucasians, Asians, and Africans. Stratified analysis by source of control revealed significant association in ND subgroup (homozygous: $\mathrm{OR}=1.83,95 \% \mathrm{CI}=1.30-2.56$ ); heterozygous: $\mathrm{OR}=1.30,95 \% \mathrm{CI}=1.03-1.64$, recessive: $\mathrm{OR}=1.54,95 \% \mathrm{CI}=1.08-2.22$; dominant: $\mathrm{OR}=1.44,95 \%$ $\mathrm{CI}=1.19-1.76$ ), rather than in $\mathrm{PB}$ and HB subgroups.

A significant heterogeneity existed in the overall pooled analysis for the association of interest under all genetic models, as indicated by the $P$ values of heterogeneity test $\left(P^{\text {het }}\right)$ in the Table 2 . Moreover, in the analyses stratified by cancer type, ethnicity, and source of control, significant heterogeneity was detected in prostate cancer, Asians, and in HB studies, respectively. Heterogeneity indicates diversity, which may result from differences in subjects, genotyping method, study design, sample size, ethnicity, and many other factors varying across studies. Therefore, the Mantel-Haenszel random effects model was used to decrease the effect of heterogeneity in these cases.

We assessed validity of the results by sensitivity analyses and examination of potential publication bias. Sensitivity analysis revealed that no individual study substantially altered the pooled results, showing the stability of the present meta-analysis (Supplementary Figure 1). The meta-analysis was free of publication bias, as indicated by symmetrical funnel plots (Figure 3), and by the Egger's linear regression test (homozygous: $P=0.461$; heterozygous: $P=0.085$; recessive: $P=0.229$; dominant: $P=0.27$; allele contrast: $P=0.938$ ).

\section{DISCUSSION}

The current meta-analysis demonstrates that the FGFR rs351855 G $>$ A polymorphism is associated with an increased cancer risk. Consistent with our study, a previous meta-analysis in 2010, which included 12 studies with 4,892 cases and 3,663 controls, suggested that the FGFR rs351855 G>A polymorphism conferred increased genetic susceptibility to cancer [40]. The same meta-analysis also showed that the rs351855 G>A polymorphism significantly elevated the risk of prostate cancer and breast cancer [40]. However, in the analysis stratified by cancer type, only three studies for breast cancer were included, and no study for lung cancer was reported [40]. Since 2010, new studies have emerged. The current meta-analysis of 27 studies comprising 8,682 cases and 9,731 controls, confirmed the increased cancer risk of the rs351855 $\mathrm{G}>\mathrm{A}$ polymorphism with increased statistical power. Moreover, our results indicate that the FGFR4 rs351855 G>A polymorphism increases the risk of prostate and breast cancer, but decreases the risk of lung cancer. The reasons why the FGFR4 rs351855 G>A polymorphism has opposite effects on different types of cancer are unclear, suggesting that other genetic and environmental factors might be involved, or that this polymorphism modifies cancer susceptibility in a tissuespecific manner. Alternatively, the association found with lung cancer might not be noteworthy, since only 
Table 1: Characteristics of studies included in the current meta-analysis

\begin{tabular}{|c|c|c|c|c|c|c|c|c|c|c|c|c|c|c|c|c|c|}
\hline \multirow[t]{2}{*}{ Surname } & \multirow[t]{2}{*}{ Year } & \multirow{2}{*}{$\begin{array}{l}\text { Cancer } \\
\text { type }\end{array}$} & \multirow[t]{2}{*}{ Country } & \multirow[t]{2}{*}{ Ethnicity } & \multirow[t]{2}{*}{ Design } & \multirow{2}{*}{$\begin{array}{l}\text { Genotype } \\
\text { method }\end{array}$} & \multicolumn{4}{|c|}{ Case } & \multicolumn{4}{|c|}{ Control } & \multirow[t]{2}{*}{ MAF } & \multirow[t]{2}{*}{ HWE } & \multirow[t]{2}{*}{ Score } \\
\hline & & & & & & & GG & $\mathbf{A G}$ & $\mathbf{A A}$ & All & GG & $\mathbf{A G}$ & AA & All & & & \\
\hline Bange & 2002 & Breast & Russia & Caucasian & PB & PCR-RFLP & 26 & 28 & 7 & 61 & 55 & 60 & 8 & 123 & 0.31 & 0.114 & 7 \\
\hline Bange & 2002 & Breast & Germany & Caucasian & PB & PCR-RFLP & 41 & 34 & 9 & 84 & 55 & 60 & 8 & 123 & 0.31 & 0.114 & 8 \\
\hline Bange & 2002 & $\mathrm{CRC}$ & Italy & Caucasian & PB & PCR-RFLP & 37 & 38 & 7 & 82 & 55 & 60 & 8 & 123 & 0.31 & 0.114 & 8 \\
\hline Morimoto & 2003 & Sarcomas & Japan & Asian & NA & PCR-RFLP & 54 & 72 & 17 & 143 & 39 & 50 & 13 & 102 & 0.37 & 0.624 & 6 \\
\hline Wang & 2004 & Prostate & USA & Caucasian & $\mathrm{PB}$ & PCR-RFLP & 125 & 117 & 42 & 284 & 53 & 40 & 4 & 97 & 0.25 & 0.291 & 7 \\
\hline Wang & 2004 & Prostate & USA & African & PB & PCR-RFLP & 37 & 6 & 2 & 45 & 76 & 18 & 0 & 94 & 0.10 & 0.305 & 6 \\
\hline Spinola & 2005 & Lung & Italy & Caucasian & $\mathrm{HB}$ & Pyrosequencing & 148 & 103 & 23 & 274 & 193 & 168 & 40 & 401 & 0.31 & 0.699 & 11 \\
\hline Spinola & 2005 & Breast & Italy & Caucasian & $\mathrm{HB}$ & Pyrosequencing & 67 & 55 & 20 & 142 & 112 & 83 & 25 & 220 & 0.30 & 0.117 & 10 \\
\hline Spinola & 2005 & $\mathrm{CRC}$ & Italy & Caucasian & HB & Pyrosequencing & 98 & 63 & 18 & 179 & 112 & 83 & 25 & 220 & 0.30 & 0.117 & 10 \\
\hline Mawrin & 2006 & Glioma & Germany & Caucasian & $\mathrm{HB}$ & PCR-RFLP & 39 & 51 & 4 & 94 & 10 & 13 & 2 & 25 & 0.34 & 0.428 & 10 \\
\hline $\mathrm{Ma}$ & 2008 & Prostate & Japan & Asian & $\mathrm{HB}$ & PCR-RFLP & 163 & 196 & 133 & 492 & 67 & 87 & 25 & 179 & 0.38 & 0.701 & 10 \\
\hline Ansell & 2009 & HNSCC & Sweden & Caucasian & PB & PCR-RFLP & 61 & & $49^{\mathrm{a}}$ & 110 & 81 & & $111^{\mathrm{a}}$ & 192 & I & l & 10 \\
\hline FitzGerald & 2009 & Prostate & USA & Caucasian & PB & SNPlex & 587 & 544 & 123 & 1254 & 631 & 496 & 124 & 1251 & 0.30 & 0.070 & 15 \\
\hline FitzGerald & 2009 & Prostate & USA & African & PB & SNPlex & 104 & 39 & 3 & 146 & 60 & 18 & 2 & 80 & 0.14 & 0.646 & 13 \\
\hline Ho & 2009 & $\mathrm{HCC}$ & Singapore & Asian & PB & Sequencing & 27 & 17 & 14 & 58 & 30 & 38 & 20 & 88 & 0.44 & 0.241 & 8 \\
\hline Naidu & 2009 & Breast & Malaysia & Asian & $\mathrm{HB}$ & PCR-RFLP & 179 & 172 & 36 & 387 & 132 & 105 & 15 & 252 & 0.27 & 0.322 & 9 \\
\hline Nan & 2009 & Skin & USA & Caucasian & PB & Taqman & 365 & 325 & 78 & 768 & 406 & 343 & 84 & 833 & 0.31 & 0.359 & 12 \\
\hline Ho & 2010 & Prostate & UK & Caucasian & $\mathrm{PB}$ & Taqman & 183 & 182 & 32 & 397 & 150 & 117 & 24 & 291 & 0.28 & 0.860 & 10 \\
\hline Tanuma & 2010 & OSCC & Japan & Asian & $\mathrm{HB}$ & PCR-SSCP & 69 & 53 & 28 & 150 & 42 & 48 & 10 & 100 & 0.34 & 0.487 & 7 \\
\hline Batschauer & 2011 & Breast & Brazil & Caucasian & PB & PCR-RFLP & 39 & 26 & 3 & 68 & 47 & 35 & 3 & 85 & 0.24 & 0.249 & 8 \\
\hline Heinzle & 2012 & $\mathrm{CRC}$ & Austria & Caucasian & PB & Taqman & 190 & 148 & 25 & 363 & 802 & 723 & 135 & 1660 & 0.30 & 0.114 & 14 \\
\hline Yang & 2012 & $\mathrm{HCC}$ & China & Asian & $\mathrm{HB}$ & Taqman & 216 & 351 & 144 & 711 & 247 & 361 & 132 & 740 & 0.42 & 0.996 & 13 \\
\hline Fang & 2013 & Lung & China & Asian & $\mathrm{HB}$ & Sequencing & 193 & 331 & 105 & 629 & 163 & 391 & 175 & 729 & 0.51 & 0.049 & 11 \\
\hline Shen & 2013 & Gastric & China & Asian & PB & Sequencing & 118 & 124 & 62 & 304 & 132 & 188 & 72 & 392 & 0.42 & 0.724 & 12 \\
\hline Gao & 2014 & NHL & China & Asian & NA & PCR-RFLP & 117 & 189 & 115 & 421 & 171 & 240 & 75 & 486 & 0.40 & 0.541 & 8 \\
\hline Jiang & 2015 & Breast & China & Asian & NA & SNaPshot & 205 & 404 & 138 & 747 & 270 & 348 & 98 & 716 & 0.38 & 0.398 & 11 \\
\hline Sheu & 2015 & $\mathrm{HCC}$ & China & Asian & $\mathrm{HB}$ & Taqman & 82 & 150 & 57 & 289 & 159 & 314 & 122 & 595 & 0.47 & 0.146 & 10 \\
\hline
\end{tabular}

Abbreviations: MAF, minor allele frequency; HWE, Hardy-Weinberg equilibrium, CRC, colorectal cancer; HNSCC, head and neck squamous cell carcinoma; HCC, hepatocellular carcinoma; OSCC, oral squamous cell carcinoma; NHL, non-Hodgkin lymphoma; PB, population based; HB, hospital based; PCR-RFLP, polymorphism chain reaction-restriction fragment length polymorphism; PCR-SSCP, polymorphism chain reaction-single-stranded conformation polymorphism.

${ }^{a}$ data was provided for $\mathrm{AG} / \mathrm{AA}$.

two studies were involved. Other two meta-analyses were performed regarding the FGFR rs $351855 \mathrm{G}>\mathrm{A}$ polymorphism [41, 42]. However, one study focused on the association between the polymorphism and prognosis (nodal status and overall survival) [41], and the other analysis only included studies on prostate cancer [42].

Interestingly, the FGFR rs351855 G>A polymorphism genotypes are distributed differently among different ethnic groups $[23,40]$. The current meta-analysis confirmed that the FGFR $\mathrm{Arg}^{388}$ allele is the most prevalent in Asians (40.1\%), and then Caucasians (30.4\%), and Africans (11.7\%). However, analysis stratified by ethnicity failed to find any ethnic-specific association between the $F G F R$ rs $351855 \mathrm{G}>$ A polymorphism and cancer risk. That is inconsistent with the previous meta-analysis study [40], which reported a significant association in Asians, with almost half the sample size (11 studies vs. 6 studies).

The biological effect of the FGFR4 Arg388 expression remains unclear. However, several lines of evidence indicate the implication of the rs351855 G>A polymorphism in carcinogenesis. In vitro experiments with triple negative breast cancer cells (MDA-MB-231) demonstrated that cells expressing the FGFR4 Arg388 variant have increased motility compared with cells expressing the FGFR4 widetype counterpart (Gly388) [18]. Wang et al. reported that compared to Gly388 cDNAs, transfection of FGFR-4 Arg388 cDNAs promoted migration and invasion of PNT1A cells (prostatic epithelial cell line) [23].

However, no correlation has been established yet between the FGFR4 rs351855 G>A genotype and 
FGFR4 protein levels. A previous study did not detect any correlation between the FGFR4 rs351855 G>A genotype and FGFR4 protein expression among 104 HNSCC patients [43]. In addition, the Gly388Arg polymorphism did not alter FGFR4 protein expression in normal lung tissue [28]. FGFR4 serves as a receptor tyrosine kinase. However, the rs351855 $\mathrm{G}>\mathrm{A}$ polymorphism did not alter the tyrosine kinase activity of FGFR4 in breast cancer [18] and prostate cancer cells [23]. Therefore, the SNP may increase cancer risk through other mechanisms, including altering FGFR4's ligand affinity, degradation, or its capacity to interact with downstream effectors. In this regard, Tateno et al. found that the FGFR4 polymorphism contributes to pituitary tumorigenesis through increasing phosphorylation of the mitochondrial STAT, resulting in increased cell growth [44]. Ulaganathan and Ullrich have recently reported that replacement of the glycine residue with a charged arginine residue at codon 388 causes changes in the transmembrane region, which consequently exposes a membrane-proximal cytoplasmic STAT3 binding site Y390-(P)XXQ393 [45]. Such de novo exposure of the STAT3 binding site facilitates STAT3 tyrosine phosphorylation, thereby stimulating cell proliferation [45]. Collectively, the FGFR4 rs351855 G>A polymorphism may promote tumorigenesis by enhancing cell migration, invasion, and proliferation. More studies are needed to validate the association and investigate the underlying mechanisms. This SNP may hold a promise as a potential chemotherapeutic target and a biomarker to screen high-risk individuals.

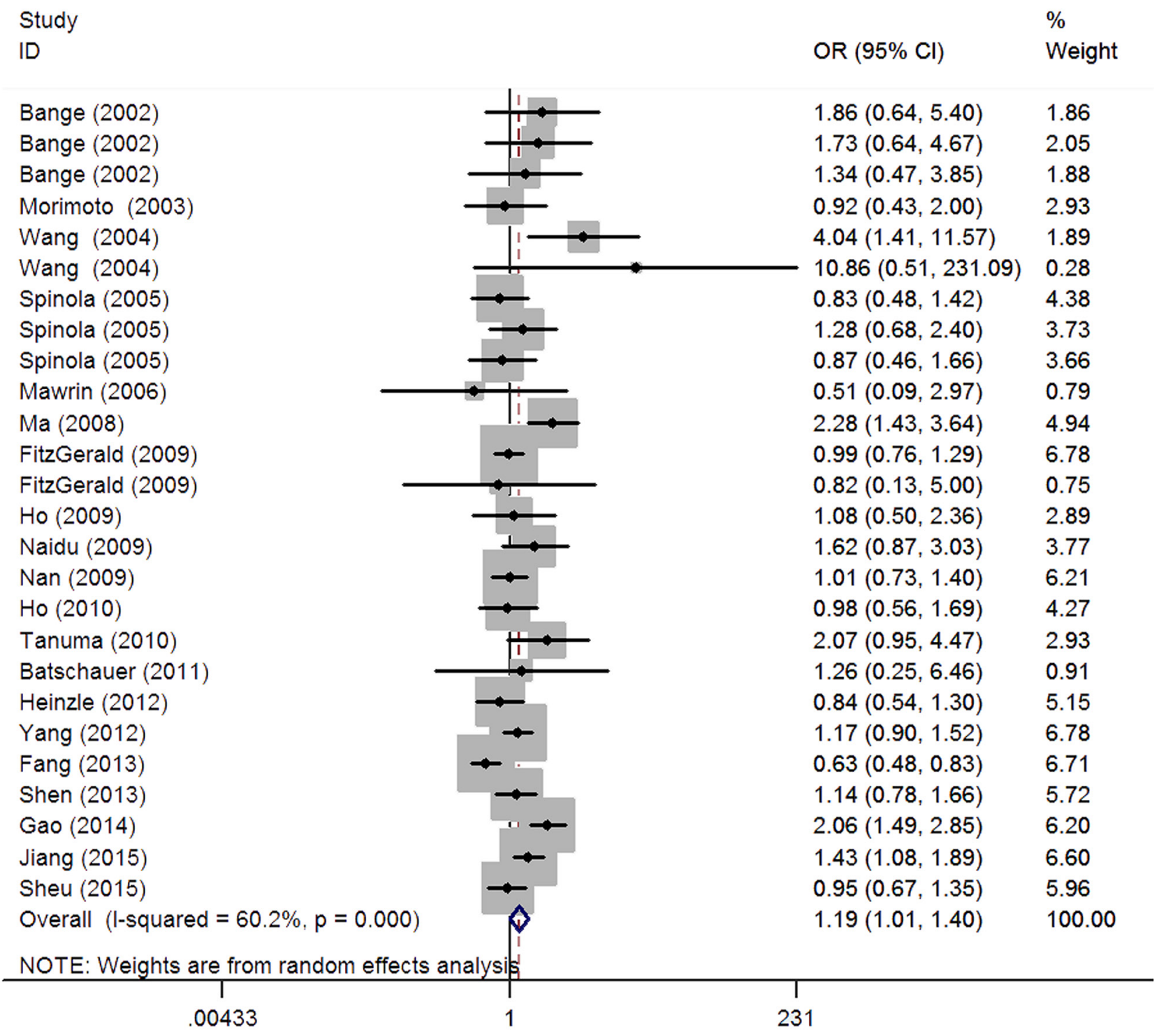

Figure 2: Forest plot of the association between the FGFR4 rs351855 G>A polymorphism and cancer risk under the recessive model. 
Table 2: Meta-analysis of the association between FGFR4 rs351855 G>A polymorphism and cancer risk

\begin{tabular}{|c|c|c|c|c|c|c|c|c|c|c|c|}
\hline \multirow[t]{3}{*}{ Variables } & \multirow{3}{*}{$\begin{array}{c}\text { No. of } \\
\text { studies }\end{array}$} & \multicolumn{2}{|c|}{ Homozygous } & \multicolumn{2}{|c|}{ Heterozygous } & \multicolumn{2}{|c|}{ Recessive } & \multicolumn{2}{|c|}{ Dominant } & \multicolumn{2}{|c|}{ Allele } \\
\hline & & \multicolumn{2}{|c|}{ AA vs. GG } & \multicolumn{2}{|c|}{ AG vs. GG } & \multicolumn{2}{|c|}{ AA vs. AG/GG } & \multicolumn{2}{|c|}{ AG/AA vs. GG } & \multicolumn{2}{|c|}{ A vs. $\mathbf{G}$} \\
\hline & & $\begin{array}{c}\text { OR } \\
(95 \% \text { CI })\end{array}$ & $P^{\text {het }}$ & $\begin{array}{c}\text { OR } \\
(95 \% \text { CI })\end{array}$ & $P^{\text {het }}$ & $\begin{array}{c}\text { OR } \\
(95 \% \mathrm{CI})\end{array}$ & $P^{\text {het }}$ & $\begin{array}{c}\text { OR } \\
(95 \% \mathrm{CI})\end{array}$ & $P^{\text {het }}$ & $\begin{array}{c}\text { OR } \\
(95 \% \text { CI) }\end{array}$ & $P^{\text {het }}$ \\
\hline All a & 27 & $\begin{array}{c}1.19 \\
(0.98-1.44)\end{array}$ & $<0.001$ & $\begin{array}{c}1.00 \\
(0.91-1.10)\end{array}$ & 0.012 & $\begin{array}{c}1.19 \\
(1.01-1.41)\end{array}$ & $<0.001$ & $\begin{array}{c}1.02 \\
(0.91-1.13)\end{array}$ & $<0.001$ & $\begin{array}{c}1.07 \\
(0.98-1.16)\end{array}$ & $<0.001$ \\
\hline \multicolumn{12}{|l|}{ Cancer type } \\
\hline Breast & 6 & $\begin{array}{c}1.73 \\
(1.35-2.20)\end{array}$ & 0.960 & $\begin{array}{c}1.17 \\
(0.95-1.45)\end{array}$ & 0.186 & $\begin{array}{c}1.46 \\
(1.17-1.83)\end{array}$ & 0.986 & $\begin{array}{c}1.25 \\
(1.02-1.52)\end{array}$ & 0.197 & $\begin{array}{c}1.26 \\
(1.14-1.41)\end{array}$ & 0.622 \\
\hline $\mathrm{CRC}$ & 3 & $\begin{array}{c}0.84 \\
(0.59-1.19)\end{array}$ & 0.701 & $\begin{array}{c}0.87 \\
(0.72-1.06)\end{array}$ & 0.964 & $\begin{array}{c}0.89 \\
(0.63-1.26)\end{array}$ & 0.718 & $\begin{array}{c}0.87 \\
(0.72-1.04)\end{array}$ & 0.895 & $\begin{array}{c}0.90 \\
(0.78-1.04)\end{array}$ & 0.773 \\
\hline Others & 7 & $\begin{array}{c}1.25 \\
(0.85-1.84)\end{array}$ & 0.017 & $\begin{array}{c}0.96 \\
(0.81-1.14)\end{array}$ & 0.290 & $\begin{array}{c}1.30 \\
(0.92-1.85)\end{array}$ & 0.019 & $\begin{array}{c}0.96 \\
(0.77-1.18)\end{array}$ & 0.040 & $\begin{array}{c}1.09 \\
(0.92-1.30)\end{array}$ & 0.022 \\
\hline Prostate & 6 & $\begin{array}{c}1.60 \\
(0.99-2.61)\end{array}$ & 0.020 & $\begin{array}{c}1.16 \\
(1.02-1.32)\end{array}$ & 0.714 & $\begin{array}{c}1.56 \\
(0.92-2.65)\end{array}$ & 0.004 & $\begin{array}{c}1.20 \\
(1.06-1.35)\end{array}$ & 0.892 & $\begin{array}{c}1.22 \\
(1.06-1.41)\end{array}$ & 0.183 \\
\hline Lung & 2 & $\begin{array}{c}0.58 \\
(0.40-0.83)\end{array}$ & 0.231 & $\begin{array}{c}0.75 \\
(0.61-0.91)\end{array}$ & 0.596 & $\begin{array}{c}0.67 \\
(0.53-0.85)\end{array}$ & 0.388 & $\begin{array}{c}0.70 \\
(0.58-0.85)\end{array}$ & 0.332 & $\begin{array}{c}0.76 \\
(0.67-0.86)\end{array}$ & 0.358 \\
\hline $\mathrm{HCC}$ & 3 & $\begin{array}{c}1.08 \\
(0.84-1.38)\end{array}$ & 0.341 & $\begin{array}{c}0.93 \\
(0.68-1.28)\end{array}$ & 0.127 & $\begin{array}{c}1.09 \\
(0.89-1.33)\end{array}$ & 0.656 & $\begin{array}{c}0.96 \\
(0.73-1.28)\end{array}$ & 0.139 & $\begin{array}{c}1.02 \\
(0.88-1.19)\end{array}$ & 0.241 \\
\hline \multicolumn{12}{|l|}{ Ethnicity } \\
\hline Caucasians & 14 & $\begin{array}{c}1.05 \\
(0.88-1.25)\end{array}$ & 0.349 & $\begin{array}{c}1.04 \\
(0.95-1.13)\end{array}$ & 0.497 & $\begin{array}{c}1.02 \\
(0.88-1.19)\end{array}$ & 0.448 & $\begin{array}{c}1.00 \\
(0.89-1.12)\end{array}$ & 0.116 & $\begin{array}{c}1.03 \\
(0.95-1.12)\end{array}$ & 0.192 \\
\hline Asians & 11 & $\begin{array}{c}1.25 \\
(0.90-1.73)\end{array}$ & $<0.001$ & $\begin{array}{c}0.96 \\
(0.80-1.16)\end{array}$ & 0.001 & $\begin{array}{c}1.28 \\
(0.99-1.66)\end{array}$ & $<0.001$ & $\begin{array}{c}1.03 \\
(0.84-1.26)\end{array}$ & $<0.001$ & $\begin{array}{c}1.09 \\
(0.93-1.28)\end{array}$ & $<0.001$ \\
\hline African & 2 & $\begin{array}{c}2.17 \\
(0.20-23.14)\end{array}$ & 0.169 & $\begin{array}{c}1.05 \\
(0.61-1.80)\end{array}$ & 0.322 & $\begin{array}{c}2.21 \\
(0.18-26.83)\end{array}$ & 0.019 & $\begin{array}{c}1.11 \\
(0.66-1.86)\end{array}$ & 0.617 & $\begin{array}{c}1.15 \\
(0.73-1.82)\end{array}$ & 0.948 \\
\hline \multicolumn{12}{|c|}{ Source of control } \\
\hline PB & 14 & $\begin{array}{c}1.07 \\
(0.90-1.27)\end{array}$ & 0.365 & $\begin{array}{c}1.00 \\
(0.88-1.13)\end{array}$ & 0.169 & $\begin{array}{c}1.07 \\
(0.92-1.25)\end{array}$ & 0.409 & $\begin{array}{c}0.99 \\
(0.87-1.12)\end{array}$ & 0.082 & $\begin{array}{c}1.04 \\
(0.96-1.12)\end{array}$ & 0.343 \\
\hline ND & 3 & $\begin{array}{c}1.83 \\
(1.30-2.56)\end{array}$ & 0.175 & $\begin{array}{c}1.30 \\
(1.03-1.64)\end{array}$ & 0.218 & $\begin{array}{c}1.54 \\
(1.08-2.22)\end{array}$ & 0.088 & $\begin{array}{c}1.44 \\
(1.19-1.76)\end{array}$ & 0.283 & $\begin{array}{c}1.34 \\
(1.14-1.58)\end{array}$ & 0.170 \\
\hline $\mathrm{HB}$ & 10 & $\begin{array}{c}1.08 \\
(0.77-1.51)\end{array}$ & $<0.001$ & $\begin{array}{c}0.92 \\
(0.81-1.05)\end{array}$ & 0.237 & $\begin{array}{c}1.13 \\
(0.84-1.50)\end{array}$ & $<0.001$ & $\begin{array}{c}0.96 \\
(0.81-1.13)\end{array}$ & 0.018 & $\begin{array}{c}1.02 \\
(0.87-1.18)\end{array}$ & $<0.001$ \\
\hline
\end{tabular}

Abbreviations: Het, heterogeneity; CRC, colorectal cancer; HCC, hepatocellular carcinoma; HB, Hospital based; PB, Population based; ND, not determined.
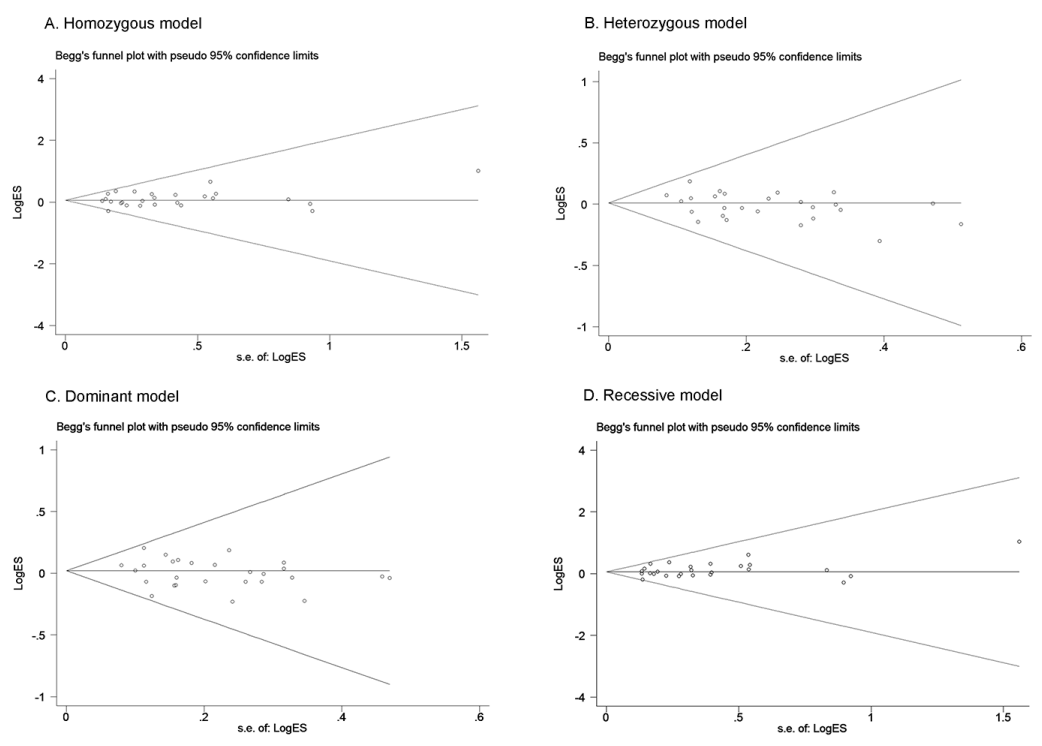

Figure 3: Funnel plots of FGFR4 rs351855 G>A polymorphism. Each point represents a separate study for the indicated association. (A) homozygous model; (B) heterozygous model; (C) dominant model; (D) recessive model. 
There were some limitations in our meta-analysis study. First, the moderate sample size might have reduced the statistical power, especially in the stratified analyses. Second, because of the unavailability of demographic and environmental information, confounding factors could not be adjusted for, including age, sex, smoking, and drinking. Since the strength of the association was measured by crude ORs, our results might be open to confounding bias. Third, publication bias may be inevitable since we were only able to acquire data from unpublished articles. Finally, the meta-analysis was associated with a significant heterogeneity, which might weaken reliability of the meta-analysis.

In conclusion, our study demonstrates the association between the FGFR4 rs351855 G>A polymorphism and overall cancer risk. In terms of cancer type, the FGFR4 rs351855 G>A polymorphism was found to modify susceptibility to breast, prostate, and lung cancer.

\section{MATERIALS AND METHODS}

The meta-analysis was performed according to the latest meta-analysis guidelines (PRISMA) [46].

\section{Data sources}

We retrieved all the published studies relating the FGFR4 rs351855 G>A polymorphism and cancer risk by searching PubMed and EMBASE databases. The combination of search terms were as follows: "FGFR4 or fibroblast growth factor receptor 4", "rs351855 or Gly388Arg", "polymorphism or variation or variant", and "cancer or carcinoma or tumor". The latest search was carried out in October 2016. We also examined the reference lists of the relevant original publications and review articles as well as previously published metaanalyses to maximize the coverage of the current metaanalysis. No language restriction was applied.

\section{Inclusion and exclusion criteria}

Inclusion and exclusion criteria were predetermined as described previously [47-49]. To be included, studies had to: (i) be case-control or cohort studies, (ii) assess the association between the FGFR4 rs351855 G>A polymorphism and cancer risk, and (iii) provide adequate data for calculating odd ratios (ORs) and $95 \%$ confidence intervals (CIs). We discarded case reports, case only studies, review articles, and conference abstracts. Additionally, we excluded studies that departed from Hardy-Weinberg equilibrium (HWE) $\left(P_{\text {нWE }}<0.05\right)$ in controls, if there was no extra evidence from another FGFR4 polymorphism satisfying HWE. When duplicate studies occurred, only the most recent or the largest study was included.

\section{Data extraction}

Two investigators (Fen Feng and Jianqun Ma) obtained data from individual studies independently following a standardized data extraction form. Data were extracted by name of the first author, year of publication, country where the study was conducted, ethnicity, genotype counts of cases and controls for the FGFR4 $\mathrm{rs} 351855 \mathrm{G}>\mathrm{A}$ polymorphism, source of controls (controls were chosen from the general population or a hospital), genotype method, and the $P$-value of HWE in controls. The subgroups were defined by cancer type, ethnicity, and source of control [hospital-based (HB) and population-based (PB)]. Publications containing different ethnicities, cancer types or different regions, were separated into different categories. The extracted information was imported into excel worksheets and examined for inconsistency. Conflicts were resolved by discussion between the two authors and a consensus would be reached ultimately.

\section{Quality assessment}

The quality of studies was scored based on the following criteria: representativeness of case, representativeness of control, ascertainment of cancer case, control selection, genotyping examination, HWE, and total sample size as described in previous study [50]. The final quality score ranged from 0 (lowest) to 15 (highest). A score of 9 was used as a cutoff value (high quality: $>9$; low quality: $\leq 9$ ).

\section{Statistical analysis}

A goodness-of-fit chi-square test was run to check departure from HWE for the FGFR4 rs $351855 \mathrm{G}>\mathrm{A}$ polymorphism in controls. The common measure of association across studies, the OR with $95 \%$ CI, was applied to the meta-analysis. The strength of the association between the FGFR4 rs $351855 \mathrm{G}>\mathrm{A}$ polymorphism and cancer risk was determined under the four genetic models (homozygous: AA vs. GG; heterozygous: AG vs. GG; recessive: AA vs. AG/GG; dominant: AG/AA vs. GG) and allele contrast was performed (A vs. G). We performed standard chi-square tests and the $\mathrm{I}^{2}$ statistic to quantify between-study heterogeneity [51]. If significance betweenstudy heterogeneity was detected, summary ORs $(95 \%$ Cls) were computed using a Mantel-Haenszel random effects model to decrease the effect of heterogeneity. If not, fixed effects model would take effect. Cancer type, ethnicity, and source of control were specified as study level characteristics for evaluating the source of heterogeneity using stratified analysis [52]. In order to explore the impact of each individual study on pooled risk estimates, we also carried out sensitivity analyses, which were fulfilled by leaving out one study at a time and recalculating ORs for the remaining studies. Publication 
bias was assessed through Begg's funnel plots [53] and Egger's linear regression test [54]. All analyses were conducted using STATA version 12 (Stata Corp, College Station, TX). All statistical analyses were two-sided, and a value of $P<0.05$ was considered significant.

\section{ACKNOWLEDGMENTS}

The study was supported by a grant from the Natural Science Foundation of Heilongjiang Province, China (No. H2015049), the scientific cultivation and innovation fund of JiNan University (21614305), and by Natural Science Foundation of China (81402143).

\section{CONFLICTS OF INTEREST}

The authors declare that no conflicts of interest exist.

\section{REFERENCES}

1. Torre LA, Bray F, Siegel RL, Ferlay J, Lortet-Tieulent J and Jemal A. Global cancer statistics, 2012. CA Cancer J Clin. 2015; 65:87-108.

2. Hallinan N, Finn S, Cuffe S, Rafee S, O'Byrne K and Gately $\mathrm{K}$. Targeting the fibroblast growth factor receptor family in cancer. Cancer Treat Rev. 2016; 46:51-62.

3. Kwabi-Addo B, Ozen M and Ittmann M. The role of fibroblast growth factors and their receptors in prostate cancer. Endocr Relat Cancer. 2004; 11:709-724.

4. Eswarakumar VP, Lax I and Schlessinger J. Cellular signaling by fibroblast growth factor receptors. Cytokine Growth Factor Rev. 2005; 16:139-149.

5. Powers CJ, McLeskey SW and Wellstein A. Fibroblast growth factors, their receptors and signaling. Endocr Relat Cancer. 2000; 7:165-197.

6. Schwertfeger KL. Fibroblast growth factors in development and cancer: insights from the mammary and prostate glands. Curr Drug Targets. 2009; 10:632-644.

7. Chae YK, Ranganath K, Hammerman PS, Vaklavas C, Mohindra N, Kalyan A, Matsangou M, Costa R, Carneiro B, Villaflor VM, Cristofanilli M and Giles FJ. Inhibition of the fibroblast growth factor receptor (FGFR) pathway: the current landscape and barriers to clinical application. Oncotarget. 2017; 8:16052-16074. doi: 10.18632/oncotarget.14109.

8. Saichaemchan S, Ariyawutyakorn W and Varella-Garcia M. Fibroblast Growth Factor Receptors: From the Oncogenic Pathway to Targeted Therapy. Curr Mol Med. 2016; 16:40-62.

9. Helsten T, Elkin S, Arthur E, Tomson BN, Carter J and Kurzrock R. The FGFR Landscape in Cancer: Analysis of 4,853 Tumors by Next-Generation Sequencing. Clin Cancer Res. 2016; 22:259-267.

10. Katoh $\mathrm{M}$ and Nakagama H. FGF receptors: cancer biology and therapeutics. Med Res Rev. 2014; 34:280-300.
11. Jaakkola S, Salmikangas $P$, Nylund $S$, Partanen J, Armstrong E, Pyrhonen S, Lehtovirta P and Nevanlinna H. Amplification of fgfr4 gene in human breast and gynecological cancers. Int J Cancer. 1993; 54:378-382.

12. Sahadevan K, Darby S, Leung HY, Mathers ME, Robson $\mathrm{CN}$ and Gnanapragasam VJ. Selective over-expression of fibroblast growth factor receptors 1 and 4 in clinical prostate cancer. J Pathol. 2007; 213:82-90.

13. Ho HK, Pok S, Streit S, Ruhe JE, Hart S, Lim KS, Loo HL, Aung MO, Lim SG and Ullrich A. Fibroblast growth factor receptor 4 regulates proliferation, anti-apoptosis and alpha-fetoprotein secretion during hepatocellular carcinoma progression and represents a potential target for therapeutic intervention. J Hepatol. 2009; 50:118-127.

14. Leung HY, Gullick WJ and Lemoine NR. Expression and functional activity of fibroblast growth factors and their receptors in human pancreatic cancer. Int J Cancer. 1994; 59:667-675.

15. Takahashi A, Sasaki H, Kim SJ, Kakizoe T, Miyao N, Sugimura T, Terada $M$ and Tsukamoto T. Identification of receptor genes in renal cell carcinoma associated with angiogenesis by differential hybridization technique. Biochem Biophys Res Commun. 1999; 257:855-859.

16. Streit S, Mestel DS, Schmidt M, Ullrich A and Berking C. FGFR4 Arg388 allele correlates with tumour thickness and FGFR4 protein expression with survival of melanoma patients. Br J Cancer. 2006; 94:1879-1886.

17. Johnston CL, Cox HC, Gomm JJ and Coombes RC. bFGF and aFGF induce membrane ruffling in breast cancer cells but not in normal breast epithelial cells: FGFR-4 involvement. Biochem J. 1995; 306 :609-616.

18. Bange J, Prechtl D, Cheburkin Y, Specht K, Harbeck N, Schmitt M, Knyazeva T, Muller S, Gartner S, Sures I, Wang $\mathrm{H}$, Imyanitov E, Haring HU, et al. Cancer progression and tumor cell motility are associated with the FGFR4 $\operatorname{Arg}(388)$ allele. Cancer Res. 2002; 62:840-847.

19. Naidu R, Har YC and Taib NA. Polymorphism of FGFR4 Gly388Arg does not confer an increased risk to breast cancer development. Oncol Res. 2009; 18:65-71.

20. Spinola M, Leoni VP, Tanuma J, Pettinicchio A, Frattini M, Signoroni S, Agresti R, Giovanazzi R, Pilotti S, Bertario L, Ravagnani F and Dragani TA. FGFR4 Gly388Arg polymorphism and prognosis of breast and colorectal cancer. Oncol Rep. 2005; 14:415-419.

21. Batschauer AP, Cruz NG, Oliveira VC, Coelho FF, Santos IR, Alves MT, Fernandes AP, Carvalho MG and Gomes KB. HFE, MTHFR, and FGFR4 genes polymorphisms and breast cancer in Brazilian women. Mol Cell Biochem. 2011; 357:247-253.

22. Jiang Y, Sun S, Wei W, Ren Y, Liu J and Pang D. Association of FGFR3 and FGFR4 gene polymorphisms with breast cancer in Chinese women of Heilongjiang province. Oncotarget. 2015; 6:34023-34029. doi: 10.18632/ oncotarget.5850. 
23. Wang J, Stockton DW and Ittmann M. The fibroblast growth factor receptor-4 Arg388 allele is associated with prostate cancer initiation and progression. Clin Cancer Res. 2004; 10:6169-6178.

24. Ho CK, Anwar S, Nanda J and Habib FK. FGFR4 Gly388Arg polymorphism and prostate cancer risk in Scottish men. Prostate Cancer Prostatic Dis. 2010; 13:94-96.

25. Ma Z, Tsuchiya N, Yuasa T, Inoue T, Kumazawa T, Narita S, Horikawa Y, Tsuruta H, Obara T, Saito M, Satoh S, Ogawa $\mathrm{O}$ and Habuchi T. Polymorphisms of fibroblast growth factor receptor 4 have association with the development of prostate cancer and benign prostatic hyperplasia and the progression of prostate cancer in a Japanese population. Int J Cancer. 2008; 123:2574-2579.

26. FitzGerald LM, Karlins E, Karyadi DM, Kwon EM, Koopmeiners JS, Stanford JL and Ostrander EA. Association of FGFR4 genetic polymorphisms with prostate cancer risk and prognosis. Prostate Cancer Prostatic Dis. 2009; 12:192-197.

27. Ansell A, Farnebo L, Grenman R, Roberg K and Thunell LK. Polymorphism of FGFR4 in cancer development and sensitivity to cisplatin and radiation in head and neck cancer. Oral Oncol. 2009; 45:23-29.

28. Spinola M, Leoni V, Pignatiello C, Conti B, Ravagnani F, Pastorino U and Dragani TA. Functional FGFR4 Gly388Arg polymorphism predicts prognosis in lung adenocarcinoma patients. J Clin Oncol. 2005; 23:7307-7311.

29. Fang HM, Tian G, Zhou LJ, Zhou HY and Fang YZ. FGFR4 genetic polymorphisms determine the chemotherapy response of Chinese patients with non-small cell lung cancer. Acta Pharmacol Sin. 2013; 34:549-554.

30. Yang Y, Zhou Y, Lu M, An Y, Li R, Chen Y, Lu DR, Jin L, Zhou WP, Qian J and Wang HY. Association between fibroblast growth factor receptor 4 polymorphisms and risk of hepatocellular carcinoma. Mol Carcinog. 2012; 51:515-521.

31. Sheu MJ, Hsieh MJ, Chiang WL, Yang SF, Lee HL, Lee LM and Yeh CB. Fibroblast growth factor receptor 4 polymorphism is associated with liver cirrhosis in hepatocarcinoma. PLoS One. 2015; 10:e0122961.

32. Whittle SB, Reyes S, Du M, Gireud M, Zhang L, Woodfield SE, Ittmann M, Scheurer ME, Bean AJ and Zage PE. A Polymorphism in the FGFR4 Gene Is Associated With Risk of Neuroblastoma and Altered Receptor Degradation. J Pediatr Hematol Oncol. 2016; 38:131-138.

33. Heinzle C, Gsur A, Hunjadi M, Erdem Z, Gauglhofer C, Stattner S, Karner J, Klimpfinger M, Wrba F, Reti A, Hegedus B, Baierl A, Grasl-Kraupp B, et al. Differential effects of polymorphic alleles of FGF receptor 4 on colon cancer growth and metastasis. Cancer Res. 2012; 72:5767-5777.

34. Tanuma J, Izumo T, Hirano M, Oyazato Y, Hori F, Umemura E, Shisa H, Hiai H and Kitano M. FGFR4 polymorphism,
TP53 mutation, and their combinations are prognostic factors for oral squamous cell carcinoma. Oncol Rep. 2010; 23:739-744.

35. Gao L, Feng Z, Li Q, Li L, Chen L and Xiao T. Fibroblast growth factor receptor 4 polymorphism is associated with increased risk and poor prognosis of non-Hodgkin's lymphoma. Tumour Biol. 2014; 35:2997-3002.

36. Shen YY, Lu YC, Shen DP, Liu YJ, Su XY, Zhu GS, Yin XL and Ni XZ. Fibroblast growth factor receptor 4 Gly388Arg polymorphism in Chinese gastric cancer patients. World J Gastroenterol. 2013; 19:4568-4575.

37. Nan H, Qureshi AA, Hunter DJ and Han J. Genetic variants in FGFR2 and FGFR4 genes and skin cancer risk in the Nurses' Health Study. BMC Cancer. 2009; 9:172.

38. Mawrin C, Kirches E, Diete S, Wiedemann FR, Schneider T, Firsching R, Kropf S, Bogerts B, Vorwerk CK, Kruger $\mathrm{S}$ and Dietzmann K. Analysis of a single nucleotide polymorphism in codon 388 of the FGFR4 gene in malignant gliomas. Cancer Lett. 2006; 239:239-245.

39. Morimoto Y, Ozaki T, Ouchida M, Umehara N, Ohata N, Yoshida A, Shimizu K and Inoue H. Single nucleotide polymorphism in fibroblast growth factor receptor 4 at codon 388 is associated with prognosis in high-grade soft tissue sarcoma. Cancer. 2003; 98:2245-2250.

40. Xu W, Li Y, Wang X, Chen B, Wang Y, Liu S, Xu J, Zhao $\mathrm{W}$ and Wu J. FGFR4 transmembrane domain polymorphism and cancer risk: a meta-analysis including 8555 subjects. Eur J Cancer. 2010; 46:3332-3338.

41. Frullanti E, Berking C, Harbeck N, Jezequel P, Haugen A, Mawrin C, Parise O, Jr., Sasaki H, Tsuchiya N and Dragani TA. Meta and pooled analyses of FGFR4 Gly388Arg polymorphism as a cancer prognostic factor. Eur J Cancer Prev. 2011; 20:340-347.

42. Xu B, Tong N, Chen SQ, Hua LX, Wang ZJ, Zhang ZD and Chen M. FGFR4 Gly388Arg polymorphism contributes to prostate cancer development and progression: a metaanalysis of 2618 cases and 2305 controls. BMC Cancer. 2011; 11:84.

43. Streit S, Bange J, Fichtner A, Ihrler S, Issing W and Ullrich A. Involvement of the FGFR4 Arg388 allele in head and neck squamous cell carcinoma. Int J Cancer. 2004; 111:213-217.

44. Tateno T, Asa SL, Zheng L, Mayr T, Ullrich A and Ezzat S. The FGFR4-G388R polymorphism promotes mitochondrial STAT3 serine phosphorylation to facilitate pituitary growth hormone cell tumorigenesis. PLoS Genet. 2011; 7:e1002400.

45. Ulaganathan VK and Ullrich A. Membrane-proximal binding of STAT3 revealed by cancer-associated receptor variants. Mol Cell Oncol. 2016; 3:e1145176.

46. Liberati A, Altman DG, Tetzlaff J, Mulrow C, Gotzsche PC, Ioannidis JP, Clarke M, Devereaux PJ, Kleijnen J and Moher D. The PRISMA statement for reporting systematic reviews and meta-analyses of studies that evaluate 
healthcare interventions: explanation and elaboration. BMJ. 2009; 339:b2700.

47. Zhu J, Hua RX, Jiang J, Zhao LQ, Sun X, Luan J, Lang Y, Sun Y, Shang K, Peng S and Ma J. Association studies of ERCC1 polymorphisms with lung cancer susceptibility: a systematic review and meta-analysis. PLoS One. 2014; 9:e97616.

48. Xue WQ, He YQ, Zhu JH, Ma JQ, He J and Jia WH. Association of BRCA2 N372H polymorphism with cancer susceptibility: a comprehensive review and meta-analysis. Sci Rep. 2014; 4:6791

49. Li SX, Dai QS, Chen SX, Zhang SD, Liao XY, Deng X, Chi HB, Li FJ, Zhu JH and Jiang YY. Xeroderma pigmentosum complementation group D (XPD) gene polymorphisms contribute to bladder cancer risk: a meta-analysis. Tumour Biol. 2014; 35:3905-3915.
50. He J, Liao XY, Zhu JH, Xue WQ, Shen GP, Huang SY, Chen W and Jia WH. Association of MTHFR C677T and A1298C polymorphisms with non-Hodgkin lymphoma susceptibility: evidence from a meta-analysis. Sci Rep. 2014; 4:6159.

51. Higgins JP, Thompson SG, Deeks JJ and Altman DG. Measuring inconsistency in meta-analyses. BMJ. 2003; 327:557-560.

52. Thompson SG and Sharp SJ. Explaining heterogeneity in meta-analysis: a comparison of methods. Stat Med. 1999; 18:2693-2708.

53. Begg CB and Mazumdar M. Operating characteristics of a rank correlation test for publication bias. Biometrics. 1994; 50:1088-1101.

54. Egger M, Davey Smith G, Schneider M and Minder C. Bias in meta-analysis detected by a simple, graphical test. BMJ. 1997; 315:629-634. 